\title{
Concern for the moral order in the field of human sexuality
}

Sexuality plays an important role in human life. It is a basic factor of personality, agreement with others, expressing and of experiencing human love. However, it is necessary to notice that nowadays the field of human sexuality collides with some concepts and events that make it trivialized. Modern culture separates sexuality from the man's supernatural vocation, from the integral vision of the person, and basically brings it to the aspect of urges.

In this perspective, a reference of human sexuality to the world of moral values is an incredibly important task. These values are marriage, family, procreation and love. Furthermore, the most important entities which influence the attitudes in the field of human sexuality are: family, school and church.

Key words: sexuality, morality, values, man, education, family, Church.

The reality of sex is of significant importance in the moral life of a human being. "God himself created sexuality - as the Holy Father stresses in the exhortation Amoris laetitia - which is a marvellous gift to his creatures" 1 . One can specify human sexuality as ability, tendency, need of a person to enter into internal relationships with another person trough a gift of self and acceptance of a gift from the other person. Although from the moment of conception each human being bears the reality of sex, it subjects, like everything in man, the law of progress. Psychosexual maturity consists in the inclusion of sexuality

1 Francis, Exhortation „Amoris laetitia”, no. 150. 
Moral theology

in the rational human action and in it's love for another person. The progress should lead to this.

In the field of human sexuality there is a complex progress, which easily undergoes deformation and perturbation. Each sexual disarray expresses the depreciation of the reality of sex. So we need a deliberate effort and measures to reach maturity in the field of sexuality. "If this gift needs to be cultivated and directed - teaches the Holy Father in the above-mentioned exhortation - it is to prevent the "impoverishment of an authentic value". This cultivation and care are extremely important, because an infantile human being in the sexual area brings in marriage his immaturity, which has repercussions in the moral life of spouses, frequently destroying the deepest human values of this relationship.

All these comments lead us to ask elementary questions about morality in the field of human sexuality and to attempt to provide answers. Namely: What are the contemporary phenomena and tendencies in the approach to the reality of sex? What moral values should serve sexual activity? What does it result in a personal's life? What is the motivation to pass on the young people with reference to human sexuality? These specific questions require in the current reality an urgent and clear answer, because appropriate shaped sexuality and integrated with the development of the whole personality will serve to enter into lasting relationships with others, and in the long term to build a lasting marital-family community ${ }^{3}$.

\section{The modern phenomena and tendencies in the approach to sexuality}

The currently observed phenomenon of moral confusing of every human being and whole societies influences doubtlessly the moral choices and the specific approach to human sexuality. This moral confusing is connected with the concept of human life, in which good is identified with what is easy and funny. Many people put first, what brings the selfish pleasure or a specific benefit, which leads to attitudes of hedonism and utilitarianism. Such an attitude toward life leads to moral relativism and its consequence on the sexual area is an attitude

\section{Ibidem.}

Cf.J.Augustyn, Wychowanie do integracjiseksualnej,Kraków 1994, p. 5; M.Kwiek, Pteć i miłość. Pedagogiczno-katechetyczna droga integracji u młodzieży klas IVVIII, Wrocław 1992, p. 36. 
of moral permissiveness, mainly by rejecting the fidelity and all possible orders and prohibitions in the sphere of sexuality 4 .

In modern liberal societies there has been a growing trend to treat sexuality as a sphere completely personal and autonomous, by leaving sexual behaviour of individual persons only their recognition, without the right to any external estimate. At the heart of this trend there are the views of the father of modern liberalism, which is the 19th century English philosopher J. S. Mill (1806-1873). He exalted the autonomy to the rank of the highest principle of individual and social life, making it the fundamental ethical criterion. As a consequence of such depiction every one in its own independent way has body and mind at its disposal: no one should impose him anything, unless it curtails the rights of another person ${ }^{5}$.

An expression of human sexuality are among other things its sexual needs, that is biologically, psychically and socially conditioned striving to achieve sexual satisfaction, defusing of sexual tension and experience of sensual pleasure. Although they are part of the drive to preserve the species, they are such human properties that are very individualized and, at the same time, marked with cultural context ${ }^{6}$. Sexual needs represent the human sexuality, but they don't equate with it completely. Sexual needs, like the need to eat, can be determined by a number of reasons: by the impact on the senses of external stimuli, by the experience, by the current state of the body, but also by the frustration or trauma and so on. As a result, the questions arises of whether, from the point of view of good of another person, we must accept the unconditional desire to satisfy its sexual needs? It seems not because these needs, like food craving can be an expression of addiction or momentary whims, and they do not signal a real lack existing inside the personality. There is therefore a need for an objective approach to the phenomenon of sexuality, an approach that would give importance to human sexuality and the best ways to update it. Ethics must discover the meaning of sexuality to be able to determine which sexual behaviors are appropriate and acceptable and which are not.

It should also be noted that the contemporary culture distracts human sexuality from the supernatural vocation of a man and does

4 Cf. A. Drożdż, Permisywizm moralny, Kielce 2005, p. 209-210; K. Glombik, Wspótczesny kontekst społeczno-kulturowy wychowania seksualnego. Próba diagnozy, „Family Forum” 1(2011), p. 161-166.

6 Cf.K. Obuchowski, Przez galaktykę potrzeb.Psychologiadażeńludzkich, Poznań 1995, p. 148. 
Moral theology

not see it in the context of the integral vision of the human person, narrowing it only to the aspect of urges. This leads therefore to the trivialization of human sexuality. It becomes the "commodity" for the exchange between people, an easy and convenient means of fun and entertainment. The church points to this situation, which hinders its mission: "This new context is made worse by what we observe: an eclipse of the truth about man which, among other things, exerts pressure to reduce sex to something commonplace. In this area, society and the mass media most of the time provide depersonalized, recreational and often pessimistic information. Moreover, this information does not take into account the different stages of formation and development of children and young people, and it is influenced by a distorted individualistic concept of freedom, in an ambience lacking the basic values of life, human love and the family".

Pope Benedict XVI drew the attention to one of the aspects of the trivialisation of sexuality in an interview with P. Seewald in which answering the question about the use of condoms as a protective measure against HIV infection, he said: "The so-called ABC theory has become popular also in the secular realm, which means 'abstinence be faithful-Condom', while the condom is understood only as the last measure, when the previous ones fail. This means that the fixation on the condom leads to the trivialisation of sexuality and becomes a very dangerous source of that many people do not experience their love in the sexual expression, but only a sort of drug that are applying themselves. Therefore, the fight against the banalization of sexuality is a part of the struggle that sexuality can be seen in a positive way and be able to develop positive effects on the whole human being" .

Entertaining understanding of human sexuality is today especially enhanced by the phenomenon of the commercialization of human sexuality. There has been created a powerful entertaining 'industry', bringing huge profits, which aim to "sell" human sexuality in many different ways. Many people also see their chances for more comfortable life, the huge earnings and a career in this commercial approach to their sexuality.

Behind these - and many others - phenomena of modernity lies incorrect understanding of human body. Modern culture reduces the human body to pure materiality. The body is not seen as a sign of love

$7 \quad$ Pontifical Council for the Family, The Truth and Meaning of Human Sexuality, Watykan 1995, n. 1.

$8 \quad$ Benedict XVI, Świattość świata. Papież, Kościót i znaki czasów. W rozmowie $z$ Peterem Seewaldem, transl. P. Napiwodzki, Kraków 2011, p. 129. 
and language, as a place of relations with others, but it becomes only a tool to satisfy their own selfish desires and instincts9. "Consequently, sexuality is depersonalized and treated instrumentally, too." 10

At this point on should note some social determinants of education of young people, which today also raise many concerns in the approach to human sexuality. Such a phenomenon as the "massification" of the school and therefore the "massification" of interpersonal relationships (eg. a teacher - students) do not favour the transmission of values. Therefore, very often sex education is not integrated into the whole education and becomes a kind of instruction about the mechanisms of human sexuality.

We must also remember that the extended period of learning and study makes many young people enter late in adulthood. The gap between sexual maturation and personal and social maturity here is clear and in the consumer lifestyle it is so easy to lose the true hierarchy of values, at the same time there is increasing participation of young people in social goods. Financial conditions allow many to become independent from their parents.

The approach to human sexuality negatively affects produced among many young people a way of life, which is sometimes called as a youth subculture. A manifestation of this phenomenon is, among other things extension at all costs of the youth masking the attitude of hostility towards a serious approach to many of life's problems and to accept responsibility for themselves and for others.

In this context, the scarcity and even the negative impact of the old models of sexual education is clearly seen. Silence of parents and other pedagogues, lack of the positive vision of sexuality, which manifests itself in the repressive character of sexual education (only bans and warnings), makes it difficult for young people to perceive themselves as being marked by sexuality ${ }^{11}$.

Some of the contemporary sex "education" programs proposed by proponents of sex education, do not help young people in experiencing their sexuality. A significant lack of proposed programs is that they are conceived as sets of information, without reference to their goals, which sexuality serves in human life and without referring them to the world of values. Many of these programs provides information to

Cf. John Paul II, Encyclical „Evangelium vitae”, n. 23.

10 Ibidem.

11 Cf.J.Nagórny,Ptciowośćludzka-zperspektywy chrześcijańskiego personalizmu, [in:], J. Nagórny, M. Pokrywka eds., Ptciowość ludzka w kontekście mitości. Przestanie moralne kościoła, Lublin 2005, p. 26-27. 
Moral theology

young people about the structure and activities of the human body as a sexual mode of operation and about diseases transmitted sexually. At the core of this kind of education is the assumption that sexual activity is simply a source of emotional satisfaction and physical pleasure, that not only does not require control, but it is an uncontrollable and directed by emotional feelings. The consequence of such a stand is, for example, treating pregnancy as undesirable effect of the sexual action. This type of sex education insists therefore a need for thorough knowledge of the means and methods of contraception, and calls for allowing abortion. The possibility of contracting sexually transmitted diseases and AIDS is presented as one stimulus inhibiting uncontrolled search of sexual experiences, so these programs are focused on the release of this kind of fear by the use of condoms as a way to protect themselves not only against unwanted pregnancy but prior to infection. The deeper one thinks about it, the more one realizes that for that kind of education there is the philosophy of meaninglessness of life and philosophy of despair ${ }^{12}$.

According to John Paul II, the root of these phenomena and trends is inadequate understanding of freedom, detached from the truth and lived in practice as a blind submission to instincts and urges, and consequently, violations of universally recognized moral standards. The Pope says that this type of attitude "is particularly reflected in that outlook on human sexuality according to which sexuality's dignity in service to communion and to the reciprocal donation between persons becomes degraded and thereby reduced to nothing more than a consumer good. In this case, many young people undergo an affective experience which, instead of contributing to a harmonious and joyous growth in personality which opens them outward in an act of self - giving, becomes a serious psychological and ethical process of turning inward toward self, a situation which cannot fail to have grave consequences on them in the future" ${ }^{13}$.

It is clear how important is education to the proper understanding and experiencing of human sexuality, with special emphasis on values to which sexual activity should serve. John Paul II stressed that in Familiaris consortio: "Faced with a culture that largely reduces human sexuality to the level of something common place, since it interprets and lives it in a reductive and impoverished way by linking it solely with the body and with selfish pleasure, the educational service [...]

12 Cf. K. Glombik, Wspótczesny kontekst społeczno-kulturowy wychowania seksualnego..., p. 156-161.

13 John Paul II, Apostolic exhortation „Pastores dabo vobis, no. 8. 
must aim firmly at a training in the area of sex that is truly and fully personal: for sexuality is an enrichment of the whole person-body, emotions and soul-and it manifests its inmost meaning in leading the person to the gift of the self in love" ${ }^{14}$.

\section{Moral values related to sexuality}

Today's reality shows that the end of psychosexual development is theology starting a family in the vast majority of people. Thus, the purpose of education in the field of sexuality should be to draw attention to young people about what they expect from life in the family and help them in shaping these attitudes that will enable them to live in a family full of joy and peace ${ }^{15}$.

The well-ordered world of moral values will give the motivation to actualize good in life. The first value, which the field of human sexuality should address is marriage and family. There is no doubt that people who solemnize marriage and live in family want them to be successful. A study of public opinion states that the majority of young people consider a happy and successful life in marriage and family as the highest value. It is therefore a value for which it is worth living, which is worth thinking and which should be well prepared to avoid later disappointment ${ }^{16}$.

Young people must gradually get accustomed to the disinterested gift of themselves, to respect the other person, whose human body is the outward expression, responsible for the gift of life and education of children. Education of marital-family community means detachment from many things, and especially from the self, selfless giving and being until the end. Education in fidelity is here fundamental. The faithful man does not betray anyone's friendship and love, but on the contrary he will strive for their growth and persistence. Fidelity to moral values is necessary in the personal development of a man. It is especially crucial in the marriage and family community because its lack brings

14 John Paul II, Apostolic exhortation „Familiaris consortio”, n. 37. Cf. also: Pontifical Council for the Family, The Truth and Meaning of Human Sexuality, n. 46.

$15 \quad$ Cf. K. Meissner, Wiara i płeć, Poznań 2003, p. 16.

16 Cf. J.Stala, Katecheza o matżeństwie i rodzinie w Polsce po Soborze Watykańskim II. Próba oceny, Tarnów 2003, p. 198-204. Cf. also: J. Stala, Rodzina-fundamentalne środowisko kształtowania człowieka. Pedagogiczno-katechetyczne impulsy pomocy młodym $w$ przygotowaniu do życia $w$ matżenstwie $i$ rodzinie, [in:] R. Kantor, M. Kluz eds., Matżeństwo i rodzina wcią $\dot{z}$ fundamentem nowej cywilizacji. Refleksje na kanwie dokumentu Konferencji Episkopatu Polski pt. "Stużyć prawdzie o matżeństwie i rodzinie", Tarnów 2011, p. 23. 
Moral theology

to human life often irreversible and destructive consequences in the social life. Hence, in upbringing young people should be taught that marriage is not a temporary agreement to be together but a covenant of love, freely concluded by mutual, irrevocable and personal consent, as it is defined by, among others, the Second Vatican Council ${ }^{17}$. It obliges them to maintain its unity and indissolubility. Jesus taught that "So then, what God has united, human beings must not divide" (Mk 10,9). Duty of mutual fidelity of the spouses results from the unity and indissolubility of marriage. The sixth commandment of the Decalogue reveals and guards it: "You shall not commit adultery" (Ex 20,14; Deut $5,18)$. The law of love lies at its basis, supplemented with justice and particularly social justice. The sacramental character of marriage in Christianity, excludes any other carnal intercourse outside this relationship. It assumes at the same time that the couple obey all necessary means to remain faithful, especially maintaining close relationship of conjugal love ${ }^{18}$.

It must be said that it is difficult to talk about education, if the information transmitted to the young does not take into account the conditions to make marriage successful. Young people should have a vision of their future family. They should think about what they can and should do to make their marriage and family life a source of peace and joy. The responsible teacher should teach them about all of this ${ }^{19}$.

The second value is life. This is the fundamental and closely related to sexuality. Life is transmitted sexually through intercourse. The transmission of life, which is an important function of sexuality, exceeds in humans over the range of biological functions. It is of personal dimension. By this term we mean the fact that the couple that transmits the life, is a pair of not only intelligent beings, that are able to know what they are doing, but there is also a pair of free beings, and thus they are responsible for their actions ${ }^{20}$.

In the field of procreation a human being must therefore be guided by reason and is burdened with the responsibility for the transmission

17 Cf. Sobór Watykański II, Konstytucja duszpasterska o Kościele w świecie wspótczesnym „Gaudium et spes”, [in:] Sobór Watykański II, Konstytucje. Dekrety. Deklaracje, Poznań 1968, n. 48. Cf. also: J. Bagrowicz, Rola rodziny w religijno-moralnej edukacji młodzieży, „Ateneum Kapłańskie” 588(2007), vol. 148, p. 232-234.

18 Cf. The Catechism of the Catholic Church, n. 2361.

19 Cf. M. Kwiek, Btędy w wychowaniu ptciowym człowieka, [in:] J. Kochel ed. Wychowanie do czystości - utopia czy zadanie, Opole 2011, p. 148-151.

20 Cf. T. Wójciak, Ptciowość ludzka, [in:] J. Nagórny, K. Jeżyna eds., Jan Pawet II, Encyklopedia Nauczania Moralnego, Radom 2005, p. 392. 
of life. The responsibility is even greater because the person who received the life, does not only have the right to live, but the right of being upbrought in the conditions of human dignity. The effects of lack of responsibility in the transmission of life are expressed not only in the fact that many human beings die of hunger. Number of abortions in the world is noted in many millions. There are countries where the number of aborted pregnancies is greater than the number of alive births. We must therefore once again emphasize that the moral duty of a man is the rational management of sexual instincts. If this does not happen, sexual life will be a disintegrating element of human and social life and will lead to the big harm of human beings.

It should also be noted that the personal dimension of the transmission of life means not only that people are those who impart life, but also that the being whose life is passed, is also a person. Believers should know that the procreation is entering into the creative action of God, because this person whose parents give life, or whose parents share their own gift of life, receives immortal soul from God. Thus, the child is simultaneously the child of parents and the creature loved by the Supreme.

Responsible teachers should therefore show young people the functionality of sexuality in procreation. In this light, the man is a human being who may be a father, and the woman is a human being who can be a mother. It is important in human life. All people live because life has been given to them by their parents.

Taking this into account in the talks with a boy could not lack the question: Will your child be happy with such a father? Similarly, a girl should answer the question: Will my child be happy, having such a mother? Young people who are in relationship should ask themselves: Do I wish my daughter to be like my girlfriend? Do I wish my son to be like my boyfriend? Will our children be proud of our love? Would I be calm about my child, if he experienced love like me? These questions relate to psychosexual development, which is family life. They arise reflection on the consequences of sexual behaviors. Responsible educators and those who create programs in the field of sex education should know and consider it.

Love is another value that in the circle of our Christian culture is associated with sex reality ${ }^{21}$. It should be realized, however, that for many

21 „Sexuality should be targeted, elevated and integrated by love, which alone makes this a truly human sexuality". Kongregacja ds. Wychowania Katolickiego, Wytyczne wychowawcze w odniesieniu do ludzkie mitości, Rzym 1983, no. 6. Cf. also: Papieska Rada ds. Rodziny, Ludzka ptciowość: prawda i znaczenie..., op. cit., no. 10-11; Papieska Rada ds. Rodziny, Wychowanie do czystej miłości. 
Moral theology people the road of love and sexuality clearly diverge, and the discovery of this often occurs too late because it so easy today to adulterate love. Without going into a detailed description of this phenomenon, one can identify at least some risk of adulteration of human love. Namely sometimes selfishness is taken for love, passion for love, admiration and infatuation for love, devotion of the for love, falling in love, affection and physical attraction for love. In the light of this possibility of deception of relationship between sexuality and love it becomes clear how important is the work of education in love ${ }^{22}$.

How, then, should be understood education in love in the context of human sex? It is important here first to say that education in love cannot be reduced to the formation of a specific dimension in human life, education cannot mean a specific sphere (eg. only the physical one). Education in love is always bringing up the whole person, the whole human being. Therefore, sex education can never be limited to the presentation of information in the field of bodily sexuality, physiology and activity of sex urges, but it should be integrated with the formation of a whole human personality ${ }^{23}$.

Education in love is also a rejection of everything that hinders the development of love. It is above all a constant struggle with the temptation to be closed in the world of selfish needs and expectations. It is a struggle with the temptation to marginalize issues of love, which is manifested in the dryness of life in false rationalization of life affairs. In this way, a person can discover the deeper perspective for the understanding of love. The point is that love is above all a personal choice. It is a free gift and acceptance of the gift"24. This "sincere gift" means that a person should not be "for the self" but for "the other". A man learns best such altruistic and selfless love in a family community. The main educational perspective of love does not relieve from portraying the concrete moral norms in this field: "In view of the close links between the sexual dimension of the person and his or her ethical values,

Wskazania dla wychowania $w$ rodzinie, Watykan 1995, no. 10-11; P. Góralczyk, Miłość podstawowa wartościa w wychowaniu seksualnym, [in:] Śladami Boga i człowieka, J. Orzeszyna ed., Kraków 2000, p. 257-269.

Cf. P. Kieniewicz, Rodzina miejscem wychowania do odpowiedzialnej miłości, [in:] Rodzina - myśl i dziatanie, G. Soszyńska ed., Lublin 2004, p. 165-174.

Cf.P.Góralczyk, Wychowanie seksualnejako wychowanie do miłości,„Pedagogia Christiana" 13(2004), no. 1, p. 155-164.

24 Cf. John Paul II, Letter to Families, Wrocław 1994, no. 11. Cf: Pontifical Council for the Family, The Truth and Meaning of Human Sexuality, op. cit., n. 9; B. M. Parysiewicz, Wychowanie do mitości. Studium z duszpasterstwa rodzin, Lublin 2010, p. 211-224. 
education must bring the children to a knowledge of and respect for the moral norms as the necessary and highly valuable guarantee for responsible personal growth in human sexuality". ${ }^{25}$

The most important is the realization by all those responsible for this type of education, that this education in love on the basis of human sexuality means education for chastity, because - as the Catechism of the Catholic Church highlights - "Chastity means the successful integration of sexuality within the person and thus the inner unity of man Moral in his bodily and spiritual being. Sexuality, in which man's belonging to the bodily and biological world is expressed, becomes personal and truly human when it is integrated into the relationship of one person to another, in the complete and lifelong mutual gift of a man and a woman. The virtue of chastity therefore involves the integrity of the person and the integrality of the gift" 26 . Thus, in the "Christian view, chastily by no means signifies rejection of human sexuality or lack of esteem for it: rather it signifies spiritual energy capable of defending love from the perils of selfishness and aggressiveness, and able to advance it towards its full realization"27.

There is also one very momentous value associated with sexual life, but seen only by believers. It's about a place that sexuality has in the foreknowledge of God the Creator. Marriage was wisely and providentially established by God, to fulfil His plan of love. The love sworn by the newlyweds, and the transmission of life participate in the life of God. Moreover, marriage is a sacrament, which means that it has the role in the saving action of Christ. This great reality is shared by humans, despite the effects of the original sin, which also affect the whole area of sexuality. The Saviour did not leave the man. He widened him the road of heart attrition, released from sin and offered him the possibility of permanent renewal of friendship with him also in married and sexual life. One has to realize that all people bear consequences of original sin, but they have been given grace. Order in the sexual field and other areas of life requires effort, but God gave man the assistance

25 John Paul II, Apostolic exhortation „Familiaris consortio”, n. 37. Cf. M. Dziewiecki, Osoba i wychowanie. Pedagogika personalistyczna w praktyce, Kraków 2003, p. 44-56.

26 The Catechism of the Catholic Church, no. 2337.

27 John Paul II, Apostolic exhortation „Familiaris consortio”, no. 33. 
of grace. Putting a lot of effort, a man can keep peace and joy in his heart always accompanying the morally good life ${ }^{28}$.

\section{Education for proper understanding and experiencing sexuality}

Moral theology
The correct form of human sexuality and its proper integration of the whole personality of the man is to establish lasting relationships with others, and at a later stage is to contribute to building a marriage and family community. For this reason, extremely important is the work of education for proper understanding and experiencing sexuality. The fundamental subjects affecting the development of appropriate attitudes in the field of human sexuality are: family, school and church. These three educational entities, through mutual cooperation are to ensure the pupils a thorough knowledge of their sexuality and help integrate their sex with the whole personality.

The most important role in the proper education in human sexuality and preparing a young man to family life takes place in the family, especially it is connected with the role of parents ${ }^{29}$. Family - as Pope Francis teaches in the encyclical Laudato Si' - is a place of integral formation, where various aspects of personal maturation take place" ${ }^{30}$. Only loving parents, on the basis of good knowledge of the psyche and his child's developmental level, and taking into account his good, may provide the relevant knowledge of sexual issues, considering the needs and expectations of the child in the certain period of life ${ }^{31}$.

Loving family helps young people to acquire skills in self-education, in the ambition to achieve inner harmony, in the management of sexuality based on values. Proper family relationships allow the acquisition of appropriate knowledge about the self, appropriate satisfying the

28 Cf. J. Bajda, Pleć a powołanie, „Studia nad Rodziną” 1(1997), no. 1, p. 17-23; S. Stefanek, Mężczyzna i niewiasta stworzyt ich. Pleć w Biblii, „Studia nad Rodziną" 1(1997), no. 1, p. 9-16.

29 See: Pontifical Council for the Family, The Truth and Meaning of Human Sexuality, 31-150.

$30 \quad$ Francis, Encyclical „Laudato Si”,, n. 213.

31 Cf.J.Augustyn, Integracja seksualna. Przewodnik w poznawaniu iksztattowaniu własnej seksualności, Kraków 1995, p. 51-52; W. Półtawska, Rola rodziców $w$ wychowaniu seksualnym młodzieży, [in:] Wychowanie $w$ rodzinie, F. Adamski ed., Kraków 2010, p. 196-197; A. Bławat, Formacja seksualna, [in:] Słownik małżeństwa i rodziny, E. Ozorowski ed., Warszawa-Łomianki 1999, p. 150. 
needs, attitudes of respect for the dignity of self and others and the acquisition of responsibility ${ }^{32}$.

In connection with the permissive sex education programs, parents should show their children the danger that exists in the early initiation of sexual intercourse, which often instead of so-called proof of love becomes the source of a sense of injustice, vamping and injuries. In our reality, when in different environments contraceptives are promoted among the youth, parents should show their children their negative effects on marriage and the value of natural family planning. Natural family planning applies not only to human activities at a given time, but primarily for its development. The attitude of this kind is an affirmation of human nature and expresses its respect for human fertility ${ }^{33}$.

The sexual life cannot be seen in isolation from certain moral values and norms. It is necessary to make young people have the right motivation, tending to initiate or discontinue certain activities in this field. The parents give the child the theoretical basis, transmit values and norms that protect them, learn how to make assessments which behaviors are valid and worthy of praise, and which should be condemned and rejected. This educational process takes place simultaneously on several levels. Feelings are formed in parallel with the transmission of information and justifications. A child with his parents accept emotionally or distances to certain ways of behaving, approves or condemns them. At the same time, with the help of parents, the child is slowly shaping its own attitudes, acquires skills of correct behavior, which can and must be called virtues ${ }^{34}$.

Healthy family is therefore the most appropriate environment shaping human sexuality, as emotional ties, trust, parents' witness and passed on the knowledge help in understanding the specific roles of men and women.

The school the most supports family in the upbringing. The school is one of the basic necessities of human civilization being of special significance for the young man and his life. Francis pointed it out in the aforementioned encyclical Laudato Si': "Good education plants seeds when we are young, and these continue to bear fruit throughout

32 Cf. D. Kornas-Biela, Ku dojrzałemu przeżywaniu płciowości, [in:] Ptciowość ludzka w kontekście mitości..., p. 150-153.

33 Cf. M. Ryś, Znaczenie wychowania i samowychowania wintegracji seksualności człowieka, „Studia nad Rodziną” 1(1997), no. 1, p. 91-92.

$34 \quad$ Cf. J. S. Szymczak, Problematyka wychowania ludzkiej ptciowości w nauczaniu Jana Pawta II, „Studia nad Rodziną” 1(1997), no. 1, p. 55-61. 
Moral theology

life" ${ }^{35}$ Teachers and educators play in it a particularly important role, especially in promoting the culture of moral life ${ }^{36}$.

Education in maturity, especially in the field of human sexuality is moral education and, as such, should demonstrate moral values for the young people, and therefore ideals worthy of realization, as well as the impact on the person to pursue and wish these values. In moral education (including sexual) it is not enough to present recognized values and protecting them moral norms and even pointing to rational reasons calling for their rightness, one still needs to properly influence on the emotional and volitional sphere of a student, in order to find delight in the presented values which will help him to overcome the difficulties on the way to the realization of these values.

In democratic countries, there is the tendency to promote so called ideological neutrality at school. In practice, this means that the school is deliberately limited to promote content that is interpersonally verifiable, while avoiding transmission of values related to the view and a certain conception of a man. Education in the field of human sexuality is associated just with the world of values, so one might ask whether the school in general has the right to deal with it. The document of the Pontifical Council for the Family, The Truth and Meaning of Human Sexuality. Guidelines for Education within the Family indicates that parents "are not always prepared to face problems connected with an education in love, may, together with their children participate in meetings conducted by experts, such as doctors, priests, educators" ${ }^{\prime 7}$.

This document also provides the basic principles, which concretized education in love: 1 . Human sexuality is a sacred mystery, which should appear in accordance with the doctrinal and moral teaching of the Church, considering the effects of original sin. 2. Children and young people can acquire the knowledge and information only to the extent adequate to the stage of their individual development. 3. Erotic material may not be presented to children and young people, regardless of age, whether individually, or in a group. 4. No one should ever be persuaded, and compelled to act in such a way that could objectively offend modesty or subjectively hurt personal sensitivity or sense of

35 Francis, Encyclical „Laudato Si’, no. 213. Cf. Franciszek, Dlaczego mam kochać szkotę? Przemówienie podczas spotkaniazuczniamiinauczycielamiszkótwłoskich (Rome - 10 maja 2014), „L'Osservatore Romano” (pol. ed.), 6(2014), p. 43-45.

Cf. S. Jasionek, Wychowanie moralne, Kraków 2004, p. 93-94. Cf. also: W. E. Pabis, Wychowanie dzieci i młodzieży do dojrzałego życia i miłości, „Studia nad Rodziną" 1(1997), n. 1, p. 86-88.

37 Pontifical Council for the Family, The Truth and Meaning of Human Sexuality, no. 31 . 
privacy $^{38}$. It seems that in the light of these principles catechists are the most competent people to conduct school education in the field of human sexuality.

A unique role in the upbringing of the value associated with the reality of sex should be attributed to the Church, because education in the field of human sexuality - as has already been said - is the moral education. Pope John Paul II in the apostolic exhortation Christifideles laici stated that: "First of all the Church is a teacher, in which the Pope takes the "primary" role in the formation of the lay faithful. As successor of Saint Peter, he has the ministry of "confirming his brothers in the faith", instructing all believers in the essential content of vocation" 39 .

For John Paul II, a man is the way of the Church, and youth - the most important stage of human life. It justifies the fact, why the Pope devoted so much attention, care and energy to young people. They will account for the future of the world, the Church and the homeland. They will build the times to come. This shaping of a young person should be done in the light of the Gospel, which as the only one thoroughly responds to the problems of today people. The Pope urged the young to be courageous in the face of life's difficulties. He urged to seize their youthful energy and natural ability to create a civilization of love. In one of his speeches to the youth he cried out: "Learn to appreciate and protect the true human love" 40 .

What most destroys the image of true love, is contained in improper look at human corporeality and sexuality. In the view of the huge publicity and propaganda of the so-called "free love" and "sex without borders" Pope John Paul II tirelessly taught young people throughout his pontificate, what is the deepest dimension of the human body and what is its significance in human love. "A man - he said - is a corporal being. This very simple statement is fraught with consequences. The human body, even though it is material but it is not a thing among other things. Firstly, in this sense it is a manifestation of a person, a way of being present among the other, communication and extremely rich expression. The body is the speech, it is the language. What's a miracle and what's the risk at the same time! Young boys and girls, have respect for your own body and the bodies of others! Let the body serve to your deepest 'I'! Let your gestures and looks be always a reflection

\section{Moral} theology . 
Moral theology

of the soul! Worship of the body? No never! Contempt for the body! No more! Control of the body! Yes! The transformation of the body! Even more!"41. The entry to the Christian lifestyle by controlling the body, cultivating purity and mutual accountability in love is a clear testimony of the doctrine of Christ and the Church.

The task of the Church as an educational environment is not only to reject erroneous theory of ethics, but also to assist in the formation of human conscience, so that in their judgments and decisions should be guided by the truth ${ }^{42}$. Moral teaching of the Church in the field of education for human sexuality is not very popular today. However, once again should be emphasized that Christ entrusted the truth to the Church, the full truth about man, and that the Church would misuse the mission, if it departed from the truth. People of good will, to whom the church directs the message, should at least try to understand the reasons for which the moral message related to human sexuality is read in the spirit of the human vocation to love and marriage ${ }^{43}$.

$$
* * *
$$

These considerations realize that sexuality is the true wealth of the human person, influencing all relationships of a personal nature; also in relation to God. Therefore, "the Church more urgently feels how irreplaceable is her mission of presenting sexuality as a value and task of the whole person, created male and female in the image of God" 4 This urgent need is dictated by the fact that modern culture seriously distorts the true meaning of human sexuality, because it separates it from its essential reference to the person and distracts its moral standards.

Because of the link between the sexual dimension of the person and the ethical values, solid formation is to lead a man to knowledge and the need to be guided by moral principles in the field of sexuality. Well-conducted formation is to lead a person to include the sexuality in the service of life and the vocation to love. Only positive vision of sexuality, revealing all its richness, indicating internal goal associated

$41 \quad$ John Paul II, Podnieście oczy ku Jezusowi Chrystusowi. Orędzie do francuskiej młodzieży (Paryż - 1 czerwca 1980), [in:] Jan Paweł II, Nauczanie papieskie, E. Weron, A. Jaroch eds., vol. III, 1, Poznań - Warszawa 1985, p. 713.

42 Cf. John Paul II, Encyclical „Veritatis splendor”, no. 84-85.

43 Cf. W. Bołoz, Etyka seksualna, Warszawa 2003, p. 94-95; A. Bławat, Formacja narzeczeńska, [in:] Słownik matżeństwa i rodziny..., p. 148-149.

44 John Paul II, Apostolic exhortation „Familiaris consortio”, no. 32. 
with the vocation of a man to love, becomes the basis for the formation of specific moral norms in this field.

Finally, one should read his sexuality in the perspective of the truth. It is thus the profound meaning of human sexuality. It was also highlighted the Pope John Paul II in the encyclical Evangelium Vitae, "It is an illusion to think that we can build a true culture of human life if we do not help the young to accept and experience sexuality and love and the whole of life according to their true meaning and in their close interconnection. Sexuality, which enriches the whole person, "manifests its inmost meaning in leading the person to the gift of self in love". .28 The trivialization of sexuality is among the principal factors which have led to contempt for new life. Only a true love is able to protect life. There can be no avoiding the duty to offer, especially to adolescents and young adults, an authentic education in sexuality and in love, an education which involves training in chastity as a virtue which fosters personal maturity and makes one capable of respecting the "spousal" meaning of the body." 45 .

\section{TROSKA O ŁAD MORALNY W DZIEDZINIE LUDZKIEJ PŁCIOWOŚCI}

Płciowość odgrywa doniosłą rolę w życiu ludzkim. Jest ona podstawowym współczynnikiem osobowości, porozumienia z innymi, wyrażania i przeżywania ludzkiej miłości. Trzeba jednak zauważyć, że dziedzina ludzkiej płciowości zderza się dzisiaj z pewnymi koncepcjami i zjawiskami, które banalizują płciowość. Współczesna kultura odrywa płciowość od nadprzyrodzonego powołania człowieka, od integralnej wizji osoby ludzkiej, a sprowadza ją wyłącznie do aspektu popędowego.

W tej perspektywie niezwykle ważnym zadaniem jest odniesienie ludzkiej płciowości do świata wartości moralnych. Tymi wartościami jest małżeństwo, rodzina, przekazywanie życia i miłość. Do najważniejszych zaś podmiotów mających wpływ na kształtowanie postaw w dziedzinie ludzkiej płciowości należy zaliczyć: rodzinę, szkołę i Kościół.

Słowa kluczowe: płciowość, moralność, wartości, człowiek, wychowanie, rodzina, szkoła, Kościół.

\section{Bibliography:}

1. Augustyn J., Integracja seksualna. Przewodnik w poznawaniu i ksztaltowaniu własnej seksualności, Kraków 1995.

45 John Paul II, Encyclical „Evangelium Vitae”, no. 97. 
Moral theology
2. Augustyn J., Wychowanie do integracji seksualnej, Kraków 1994.

3. Bagrowicz J., Rola rodziny $w$ religijno-moralnej edukacji młodzieży, „Ateneum Kapłańskie" 588(2007), vol. 148.

4. Bajda J., Pleć a powołanie, „Studia nad Rodziną” 1(1997), no. 1.

5. Benedykt XVI, Swiattość świata. Papież, Kościót i znaki czasów. W rozmowie z Peterem Seewaldem, przekł. P. Napiwodzki, Kraków 2011.

6. Bławat A., Formacja seksualna, [in:] Stownik małżeństwa i rodziny, E. Ozorowski ed., Warszawa - Łomianki 1999.

7. Bołoz W., Etyka seksualna, Warszawa 2003.

8. Drożdż A., Permisywizm moralny, Kielce 2005.

9. Dziewiecki M., Osoba i wychowanie. Pedagogika personalistyczna w praktyce, Kraków 2003.

10. Franciszek, Adhortacja apostolska „Amoris laetitia”, Częstochowa 2016.

11. Franciszek, Dlaczego mam kochać szkotę? Przemówienie podczas spotkania z uczniami i nauczycielami szkót wtoskich (Rzym - 10 maja 2014), „L'Osservatore Romano” (pol. ed.), 6(2014).

12. Franciszek, Encyklika „Laudato Si””, Kraków 2015.

13. Glombik K., Wspótczesny kontekst społeczno-kulturowy wychowania seksualnego. Próba diagnozy, „Family Forum” 1(2011).

14. Góralczyk P., Miłość podstawowa wartościa w wychowaniu seksualnym, [in:] J. Orzeszyna ed., Śladami Boga i człowieka, Kraków 2000.

15. Góralczyk P., Wychowanie seksualne jako wychowanie do mitości, „Pedagogia Christiana" 13(2004), no. 1.

16. Jan Paweł II, Adhortacja apostolska „Christifideles laici”, Poznań 1989.

17. Jan Paweł II, Adhortacja apostolska „Familiaris consortio”, Częstochowa 1991.

18. Jan Paweł II, Adhortacja apostolska „Pastores dabo vobis, Wrocław 1992.

19. Jan Paweł II, Chrystus nigdy was nie zawiedzie. Spotkanie z młodzieża na Avenida Los Proceres (Caracas - 11 lutego 1996), „L'Osservatore Romano” (wyd. pol.) 17(1996), no. 5.

20. Jan Paweł II, Encyklika „Evangelium vitae”, Kraków 1995.

21. Jan Paweł II, Encyklika „Veritatis splendor”, Wrocław 1993.

22. Jan Paweł II, List do Rodzin, Wrocław 1994.

23. Jan Paweł II, Podnieście oczy ku Jezusowi Chrystusowi. Orędzie do francuskiej młodzieży (Paryż - 1 czerwca 1980), [in:] Jan Paweł II, Nauczanie papieskie, E. Weron, A. Jaroch eds., vol. III, 1, Poznań - Warszawa 1985.

24. Jasionek S., Wychowanie moralne, Kraków 2004.

25. Katechizm Kościoła Katolickiego, Poznań 1994.

26. Kieniewicz P., Rodzina miejscem wychowania do odpowiedzialnej miłości, [in:] Rodzina - myśl i działanie, G. Soszyńska ed., Lublin 2004.

27. Kongregacja ds. Wychowania Katolickiego, Wytyczne wychowawcze w odniesieniu do ludzkie miłości, Rzym 1983.

28. Kwiek M., Błędy w wychowaniu ptciowym człowieka, [in:] Wychowanie do czystości - utopia czy zadanie, J. Kochel ed., Opole 2011.

29. Kwiek M., Płeć i miłość. Pedagogiczno-katechetyczna droga integracji u młodzieży klas IV-VIII, Wrocław 1992.

30. Meissner K., Wiara i płeć, Poznań 2003, p. 16. 
31. Mill J. S., On Liberty, Oxford 1946.

32. Nagórny J., Ptciowość ludzka - z perspektywy chrześcijańskiego personalizmu, [in:], Ptciowość ludzka w kontekście mitości. Przestanie moralne kościoła, J. Nagórny, M. Pokrywka eds., Lublin 2005.

33. Obuchowski K., Przez galaktykę potrzeb. Psychologia dążen ludzkich, Poznań 1995.

34. Pabis W. E., Wychowanie dzieci $i$ młodzieży do dojrzałego życia i mitości, „Studia nad Rodziną” 1(1997), no. 1.

35. Papieska Rada ds. Rodziny, Ludzka ptciowość: prawda i znaczenie. Wskazania dla wychowania $w$ rodzinie, Watykan 1995.

36. Papieska Rada ds. Rodziny, Wychowanie do czystej miłości. Wskazania dla wychowania $w$ rodzinie, Watykan 1995.

37. Parysiewicz B. M., Wychowanie do mitości. Studium z duszpasterstwa rodzin, Lublin 2010.

38. Półtawska W., Rola rodziców $w$ wychowaniu seksualnym młodzieży, [in:] Wychowanie $w$ rodzinie, F. Adamski ed., Kraków 2010.

39. Ryś M., Znaczenie wychowania i samowychowania $w$ integracji seksualności człowieka, „Studia nad Rodziną” 1(1997), n. 1.

40. Sobór Watykański II, Konstytucja duszpasterska o Kościele w świecie wspótczesnym „Gaudium et spes”, [in:] Sobór Watykański II, Konstytucje. Dekrety. Deklaracje, Poznań 1968.

41. Stala J., Katecheza o matżenstwie i rodzinie w Polsce po Soborze Watykańskim II. Próba oceny, Tarnów 2003.

42. Stala J., Rodzina - fundamentalne środowisko ksztattowania człowieka. Pedagogiczno-katechetyczne impulsy pomocy młodym w przygotowaniu do życia $w$ matżeństwie $i$ rodzinie, [in:] Matżeństwo i rodzina wciáż fundamentem nowej cywilizacji. Refleksje na kanwie dokumentu Konferencji Episkopatu Polski pt. „Stużyć prawdzie o matżeństwie i rodzinie”, R. Kantor, M. Kluz eds., Tarnów 2011.

43. Stefanek S., Mężczyzną i niewiasta stworzyt ich. Pteć $w$ Biblii, „,Studia nad Rodziną" 1(1997), no. 1.

44. Szymczak J. S., Problematyka wychowania ludzkiej ptciowości w nauczaniu Jana Pawta II, „Studia nad Rodziną” 1(1997), no. 1.

45. Wójciak T., Ptciowość ludzka, [w:] Jan Paweł II, Encyklopedia Nauczania Moralnego, J. Nagórny, K. Jeżyna eds., Radom 2005. 